\title{
TREATMENT AND RECYCLE OF HIGH EXPLOSIVE CONTAMINATED WATER
}

\author{
J. Greg Locke
}

SEPTEMBER 1994

Production Capability Assurance Program

Waste and Hazard Minimization

Does Not Contain

Unclassified Controlled Nuclear Information

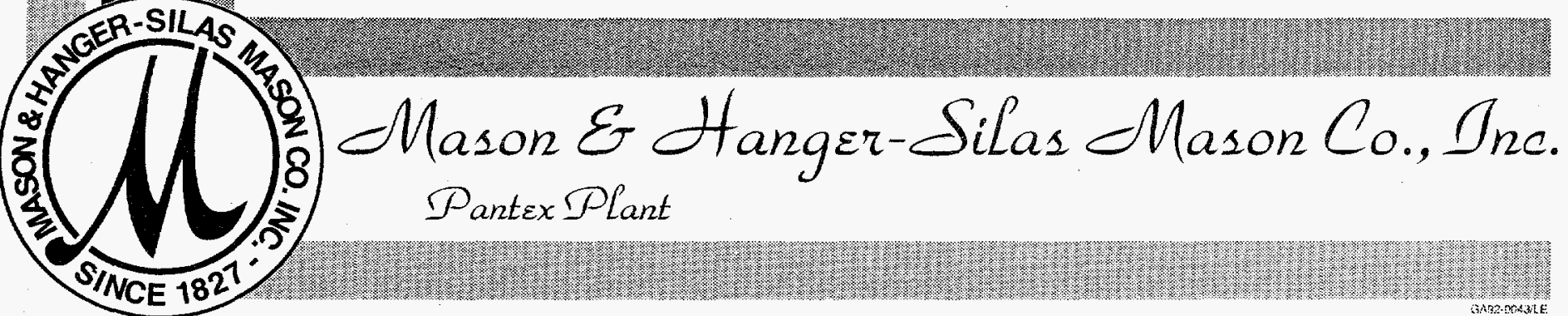

P. O. BOX 30020

AMARILLO, TEXAS 79177

806-477-3000

\section{OPERATED FOR THE \\ Department of Energy}

UNDER

U. S. GOVERNMENT CONTRACT DE-AC04-91A'-65030 DISTRIBUTION OF THIS DOCUMENT IS UNLIMITED 


\section{DISCLAIMER}

This report was prepared as an account of work sponsored by an agency of the United States Government. Neither the United States Government nor any agency thereof, nor any of their employees, makes any warranty, express or implied, or assumes any legal liability or responsibility for the accuracy, completeness, or usefulness of any information, apparatus, product, or process disclosed, or represents that its use would not infringe privately owned rights. Reference herein to any specific commercial product, process, or service by trade name, trademark, manufacturer, or otherwise does not necessarily constitute or imply its endorsement, recommendation, or favoring by the United States Government or any agency thereof. The views and opinions of authors expressed herein do not necessarily state or reflect those of the United States Government or any agency thereof.

This report has been reproduced from the best available copy. Available in paper and microfiche

Number of pages in this report: 10

DOE and DOE contractors can obtain copies of this report from:

Office of Scientific and Technical Information

P. 0. Box 62

Oak Ridge, TN 37831

(615) 576-8401

This report is publicly available from :

Department of Commerce, National Technical Information Service 5285 Port Royal Road

Springfield, VA 22161

(703) $487-4650$ 


\section{DISCLAIMER}

Portions of this document may be illegible in electronic image products. Images are produced from the best available original document. 


\title{
TREATMENT AND RECYCLE OF HIGH EXPLOSIVE CONTAMINATED WATER
}

\author{
J. Greg Locke
}

SEPTEMBER 1994

Production Capability Assurance Program Waste and Hazard Minimization

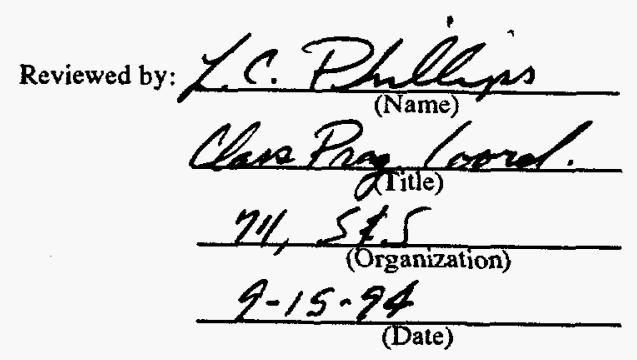




\title{
TREATMENT AND RECYCLE OF HIGH EXPLOSIVE CONTAMINATED WATER
}

\author{
J. Greg Locke
}

SEPTEMBER 1994

Production Capability Assurance Program

Waste and Hazard Minimization

\begin{abstract}
A polysulfone ultrafilter membrane having a $0.04-\mu \mathrm{m}$ pore opening has been used to filter high explosive contaminated water. The water is being recycled for the coolant used during the machining of high explosive billets.
\end{abstract}




\section{INTRODUCTION}

High explosive contaminated wastewater is generated from the machining of high explosives at Pantex Plant. The water is used as the coolant during the machining operation. Typically, the water flow rate is from 2 to 3 gallons per minute. The water must be tempered to about room temperature so that it does not affect the dimensions of the explosive piece being machined. In normal operations, the wastewater and cuttings are allowed to flow to a centralized collection system. The solid explosives are separated from the water using the process shown in Figure 1. The wastewater is collected in an air agitated receiving tank or sump. It is pumped from the sump to a settling cone where the solid particles are decanted off of the bottom. The overflow from the cone is collected in another tank and then pumped through two cyclone separators operated in series. This water is also collected in a holding tank prior to final filtration through a $25-\mu \mathrm{m}$ filter. The effluent from the particle filter flows through two activated carbon filters operated in series prior to being discharged to a drainage ditch. This results in an average discharge of about 2000 gallons per operating day from Building 11-50. This project was initiated to develop a method to treat this wastewater and recycle it to the machine, thus eliminating the discharge. 


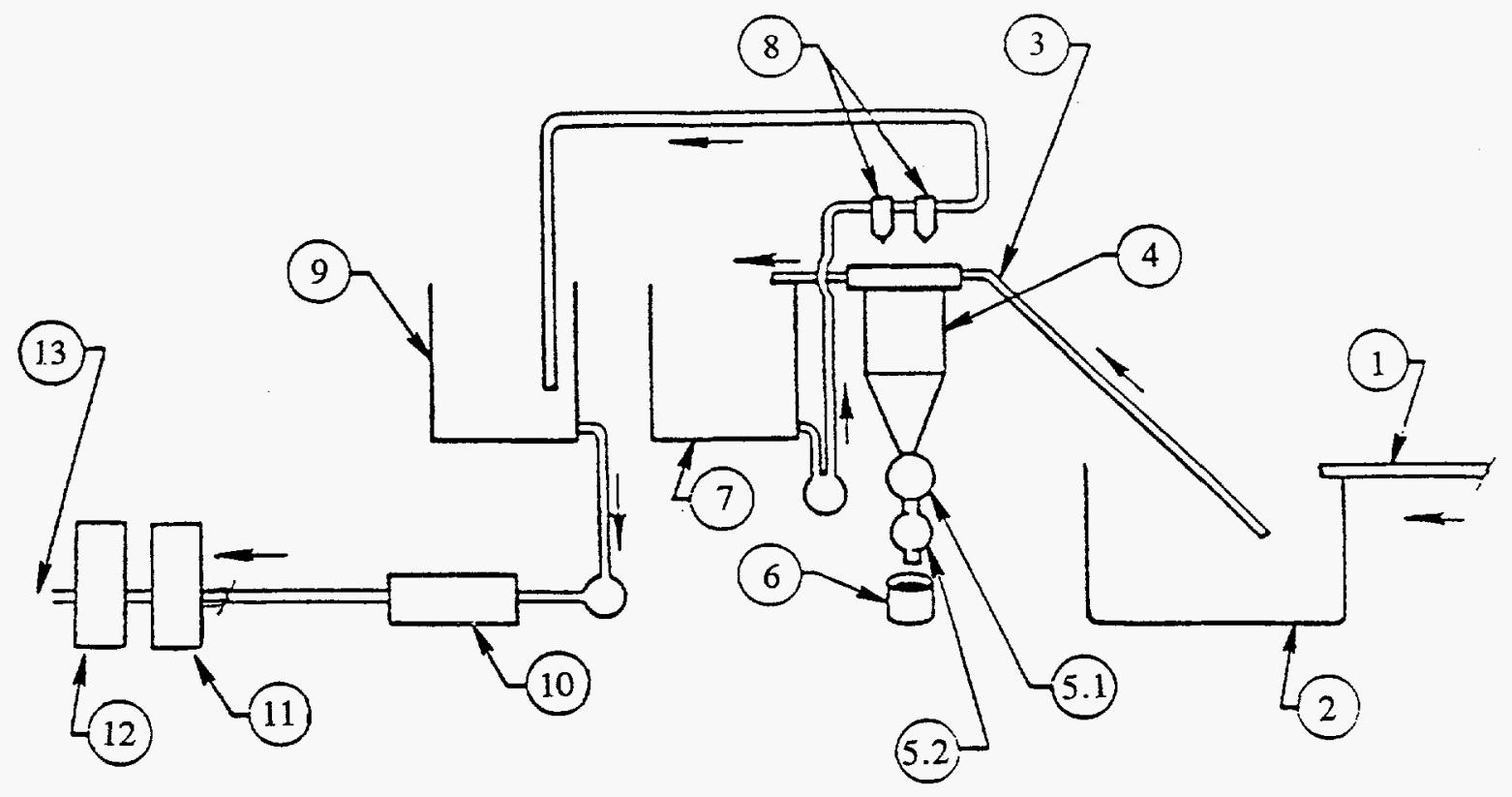

1. Contaminated water from explosives building

2. Receiving tank from flume (outside building)

3. Receiving tank water pumped to settling cone

4. Settling cone

5. Collection chamber

5.1 Air operated dump valve (upper)

5.2 Air operated dump valve (lower)

6. Plastic collection can

7. Holding tank

8. Cyclone separators

9. Final Holding tank

10. Final filtration system

11. Carbon filter

12. Carbon filter

13. Discharge water

Figure 1. Building 11-50 Wastewater Filtration System 


\section{DISCUSSION}

The wastewater from machining operations is contaminated with solid and dissolved explosives and oils from lubricating the machine weighs. Most of the solid explosives are collected at the machine using a $100-\mu$ felt filter bag. The dissolved explosive concentration varies with the type of plastic bonded explosive (PBX) being machined. The concentration with TATB (1,3,5-triamino-2,4,6-trinitrobenzene) based explosives is below the detection limit of $10 \mathrm{ppb}$. The concentration for HMX (1,3,5,7-tetranitro1,3,5,7-tetraza-cyclooctane) based explosives is about 5 to $10 \mathrm{ppm}$ of both HMX and RDX (1,3,5-trinitro1,3,5-triazacyclohexane). RDX is an impurity of HMX.

The purpose of this project was to develop a process to produce water pure enough to allow it to be safely recycled to the machine and reused as a coolant. The major safety concerns were handling of high explosive particulates and dissolved explosives. The quality concern was to produce water that could be recycled and reused without detrimentally affecting the quality of the explosive being machined. It was also desirable to provide a mobile system that could be easily moved between locations, was reasonably priced, and did not require any elaborate equipment or procedures to operate. Pantex personnel worked with a local industrial water treatment firm, Canatxx Services, to design and build a treatment and recycle system.

The filtration of explosive particulates from water is a standard practice at Pantex Plant and not a difficult problem. The possibility of crystallization and depositing some of the dissolved explosives from the water into threaded surfaces, etc. was a major concern. For that reason, external threads and plastics were used wherever possible in the design. Since it was not necessary to remove the dissolved explosives, this system was designed with a low pressure ultrafilter. The ultrafilter used was a Desalination Systems, Inc. E-500 series polysulfone membrane, Model No. EW4040F. It has an average pore opening of $0.04 \mu \mathrm{s}$ and an active filtration area of $96 \mathrm{ft}^{2}$. The membrane performance is given in Table 1 . 


\begin{tabular}{|c|c|c|c|c|c|}
\hline \multirow[b]{2}{*}{ Compound } & \multirow[b]{2}{*}{$\begin{array}{l}\text { Molecular } \\
\text { Weight }\end{array}$} & \multirow[b]{2}{*}{$\begin{array}{c}\text { Rejection } \\
(\%)\end{array}$} & \multicolumn{3}{|c|}{ Test Conditions } \\
\hline & & & $\begin{array}{c}\text { Feed } \\
(\%)\end{array}$ & $\begin{array}{l}\text { Pressure } \\
\text { (psig) }\end{array}$ & $\begin{array}{c}\text { Temperature } \\
\left({ }^{\circ} \mathrm{F}\right)\end{array}$ \\
\hline PVA & 60,000 & 98 & 11 & 60 & 181 \\
\hline Dextran & $\begin{array}{r}70,000 \\
110,000 \\
500,000 \\
\end{array}$ & $\begin{array}{l}68 \\
75 \\
96 \\
\end{array}$ & 1 & 7 & 77 \\
\hline $\begin{array}{l}\text { Polyethylene } \\
\text { Glycol }\end{array}$ & $\begin{array}{r}6,750 \\
35,000 \\
5.5 \times 10^{6} \\
\end{array}$ & 93 & 6700 & 44 & 68 \\
\hline Polyacrylamide & $5.5 \times 10^{6}$ & 93 & 6700 & 44 & 68 \\
\hline
\end{tabular}

Figure 2 is a flow diagram of the system, Figure 3 shows the layout of the equipment on a $4 \times 4 \mathrm{ft}$. base, and Figure 4 is a photograph of the installed system. The wastewater and cuttings from the machining operation as with normal operations are first filtered through a $100-\mu \mathrm{m}$ felt filter bag before being discharged to the collection sump. The wastewater is pumped from the sump by an Osmonics doublediaphragm pump through the filtration system. Pressure gauges are provided on each side of every filtration device to provide differential pressure and indications of plugging. The first filtration step is through a $25-\mu \mathrm{m}$ felt filter bag. The second filtration step is through a 5- $\mu \mathrm{m}$ cartridge filter which has seven filter elements, then through two activated charcoal filters operated in series. The charcoal is to remove any oils that are picked up by the water from the machine weighs. The water flows from the activated charcoal filters to the ultrafilter. The reject water from the ultrafilter is discharged back to the sump to be recycled and the clean water is collected in a 300-gallon storage tank. A 300-gallon storage tank was chosen in order to provide enough residence time for the water to return to room temperature and not affect the explosive dimensions. Another double-diaphragm pump is used to supply water to the machine through a pressure tank which is used to dampen the pulsation flow of the diaphragm pump. 


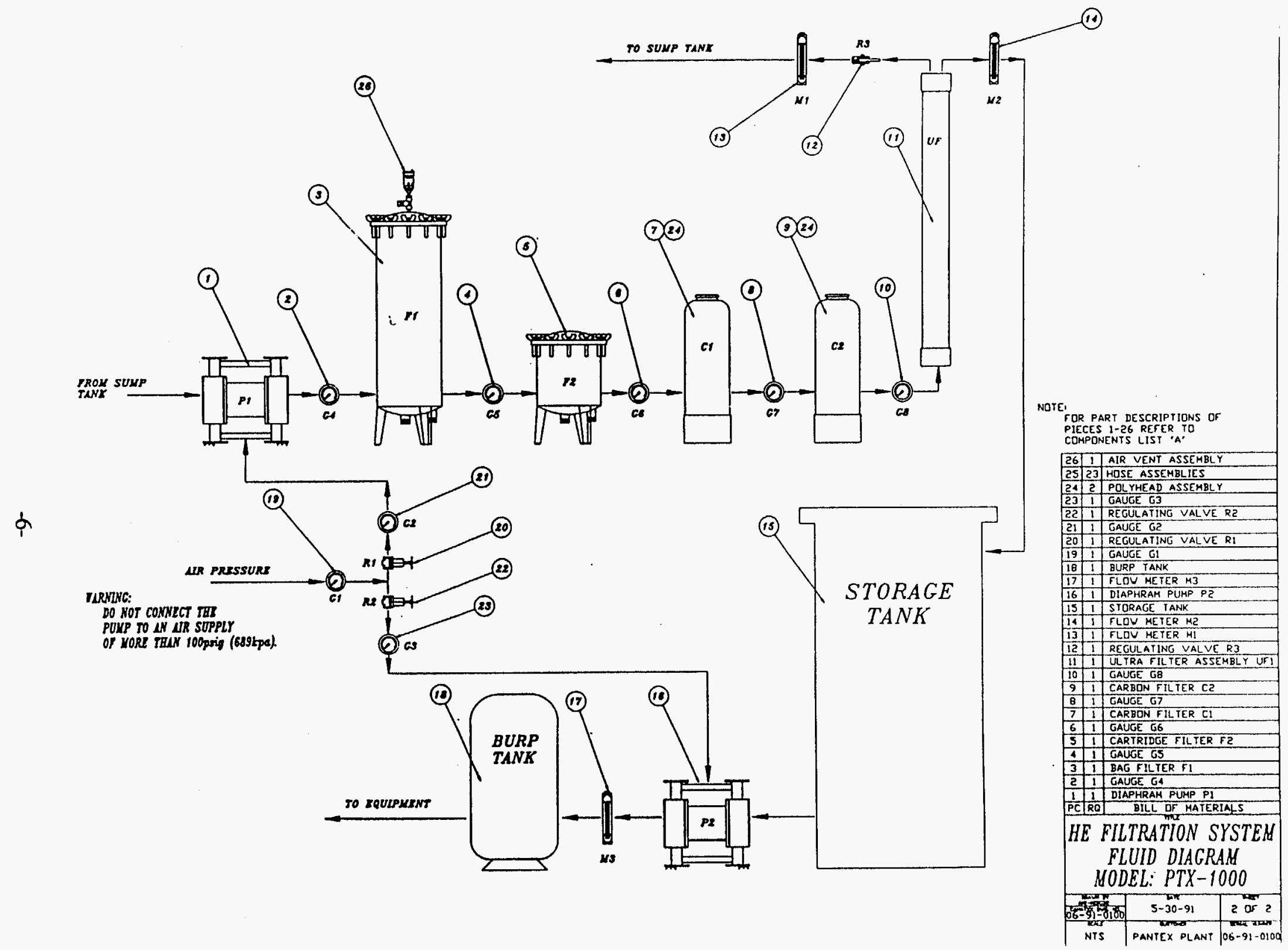

Figure 2. Flow Diagram of the System 


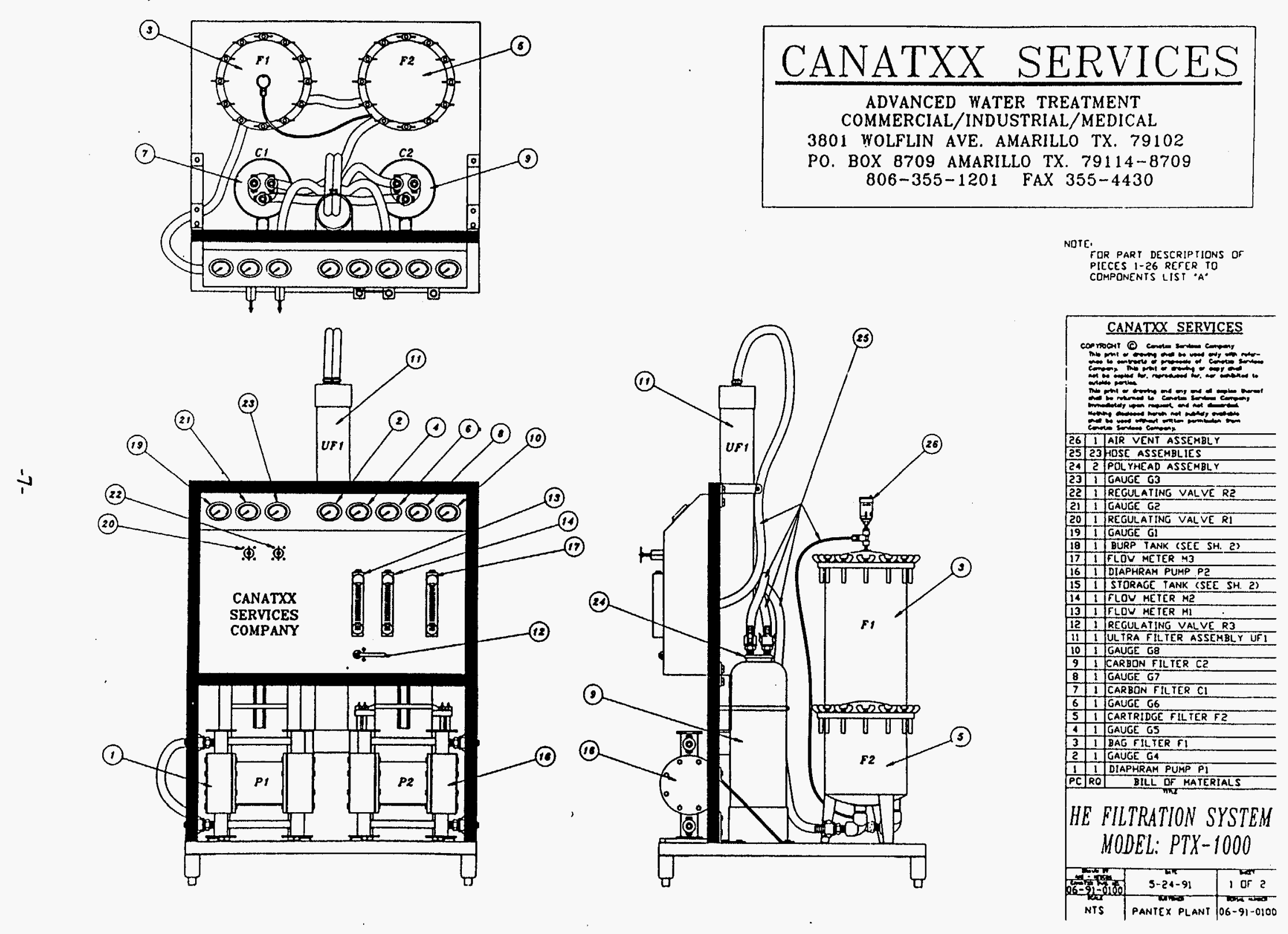

Figure 3. Layout of the Equipment on a $4 \times 4 \mathrm{Ft}$. Base 


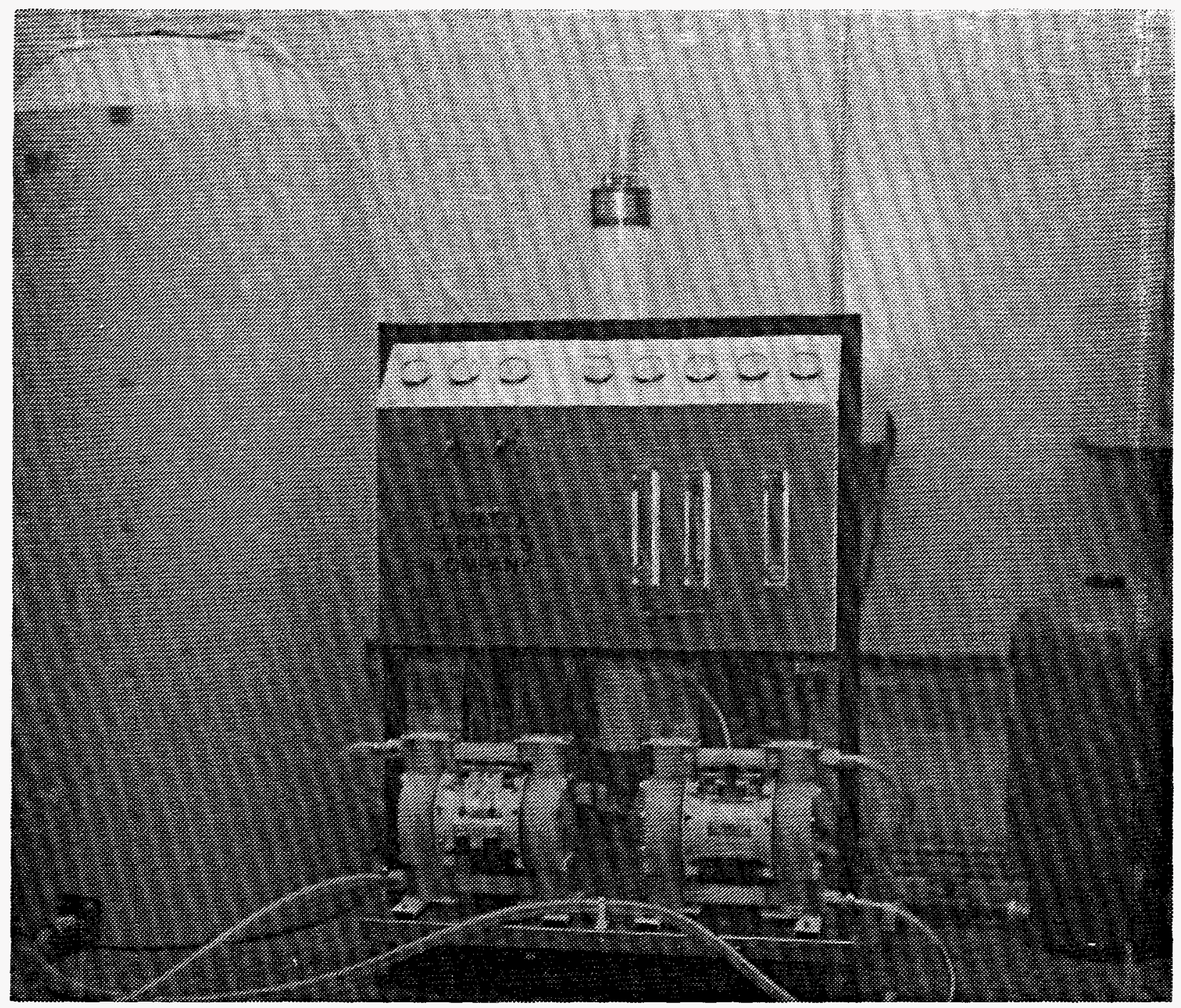

Figure 4. Photograph of Installed System

\begin{abstract}
RESULTS
This equipment was installed and has been in operation since September 1991. The maximum water flow rate through the ultrafilter is approximately 6 gallons per minute at a feed pressure of $25 \mathrm{psig}$. This is two to three times the required water flow for the machining operation. Therefore, the water flows were adjusted to about 3 gallons per minute for the reject water and 3 gallons per minute for the clean water. Initial testing of the water indicated that the dissolved explosives were being removed by the activated charcoal filters. In order to test the performance of the ultrafilter, the charcoal filters were bypassed while filtering water contaminated with PBX 9404, an HMX based explosive. The feed water from the sump contained approximately $4 \mathrm{ppm}$ of both HNXX and RDX. The clean water and the reject water from the ultrafilter both had about the same concentration of HMX and RDX as the feed water. This indicates
\end{abstract}


that the ultrafilter will not remove the dissolved explosives as expected.

In an effort to determine whether the system could be "forced" to remove the dissolved explosives, a reverse osmosis membrane was purchased and installed in the system for evaluation. The feed water was again about $4 \mathrm{ppm}$ of both HMX and RDX and the activated charcoal filters were bypassed. The HMX concentration was reduced by $92 \%$ to $0.36 \mathrm{ppm}$ and the RDX concentration was reduced to less than the detection limit of $0.05 \mathrm{ppm}$. The reverse osmosis membrane required an operating pressure of $100 \mathrm{psig}$ which is the maximum allowable for the system. Under these conditions with minimum reject water flow, the membrane would produce only 0.5 gallon per minute of clean water. This was inadequate to meet the supply need of 3 gallons per minute.

\section{CONCLUSIONS}

This wastewater filtration and recycle system has been in operation at Pantex Plant for over a year without any problems. The operators are very pleased and satisfied with the system operations. If desired or necessary, it would be possible to remove the dissolved explosives using reverse osmosis but the filtration area would have to be increased by four to six times, and the discharge pressure of the pump would have to be increased above 100 psig. 


\section{DISTRIBUTION}

DEPARTMENT OF ENERGY - WASHINGTON, DC

Director of Weapons Production

Office of Military Application

\section{DEPARTMENT OF ENERGY - AL}

Technical Information Officer, IPS

Quality Operations Branch

Weapons Quality Division

Technology Development Branch

Weapons Quality Division

Waste Management Branch

Waste Management and

Operational Surety Division

Program Support Branch

Weapon Programs Division

DEPARTMENT OF ENERGY - AAO

Area Manager

OFFICE OF SCIENTIFIC AND TECHNICAL INFORMATION - OAK RIDGE, TN

(2)

\section{LAWRENCE LIVERMORE NATIONAL LABORATORY}

L-32

L-282 (6)

\section{LOS ALAMOS NATIONAL LABORATORY}

DX-DO

DX-10

DX-16 (3)

ESA-1

ESA-2 Group Office

NWNP, F-630

ISD-4
SANDIA NATIONAL LABORATORIES - NEW MEXICO

Org. 2000

Org. 2571

Org. 2652

Org. 2600

SANDIA NATIONAL LABORATORIES - CALIFORNIA

Org. 5354

EG\&G MOUND APPLIED TECHNOLOGIES

Manager, Product and Process Development

\section{SAVANNAH RIVER LABORATORY}

Program Manager, Defense Waste Processing Section, 773-A

ALLIED-SIGNAL INC. - KANSAS CITY PLANT

Material Engineering

MASON \& HANGER - PANTEX PLANT

Operations Support

Engineering and Design Division

ES\&H/WM Directorate

Explosives Technology Division

Program Management

Quality Division

Circulation Copy:

1. W. A. Weinreich, 12-69

2. H. A. Woltermann, 11-2

Technical Library

File (5)

Please refer any distribution changes to

A. V. Lucero, Publications Section FTS 477-3535. 